\begin{tabular}{c} 
International Journal of Engineering \& Technology, $7(2.13)(2018) 276-280$ \\
International Journal of Engineering \& Technology \\
SPC \\
Website: www.sciencepubco.com/index.php/IJET \\
Research Paper \\
\hline
\end{tabular}

\title{
Modeling of electrical characteristics of photo voltaic and effecting of cell parameters on V-I curve
}

\author{
Fawaz S. Abdullah ${ }^{1}$, Safwan A. Hamoodi ${ }^{1}$, Ali N. Hamoodi ${ }^{1}$ \\ ${ }^{1}$ Technical College/ Mosul \\ *Corresponding author E-mail: Sofia196022@yahoo.com
}

\begin{abstract}
Studding of PV systems in an active way needs accurate information of the power and voltage P-V current and voltage I-V characteristic curves of solar PV order. Therefore, this paper shows emulation of solar PV model utilizes Matlab/Simulink and practical results. This PV model depends on math's equation and is explained during an equivalent circuit involving a photo current source, diode, shunt resistor and series resistor representing leakage current and series resistor expressing the inside losses because of the current flow. The advanced model let the prognosis of PV array manner under various circuit model and ecological parameters solar temperature, ray. A special model (Lcs M200 - JA/SI) solar collector using for this paper, results was compared with practical curve with different points of the curve and show good conformity to the model.
\end{abstract}

Keywords: PV Cell; P-V and I-V Characteristic; PV Temperature; PV Irradiation.

\section{Introduction}

PV panel becomes more benefit as a clean energy resource and has advantages as compared with other sources such no polluting, without fuel costs, little maintenance and no emitting noise. PV panels have relatively low efficiency, although the PV collector is presented to its rise invention cost [1]. The increase of oil praises makes solar power surely applicable energy supply for potentially long code. PV model performs the primary power transmutation unit of a PV generator orders. The collector output features on the solar temperature, ray, shunt resistance and series resistance of cell. The voltage of PV model has not straight lines characteristics, it is important to model it to the form and emulation of max power point tracking (MPPT) for the system implementation. Furthermore to math's modelling and simulation of the model can investigator to have a best understanding of its paper. This modelling mostly includes the effect of the not straight lines P-V and I-V curves [1], [2].

\section{Mathematical equations of solar PV Cell}

Many equivalent circuits of a solar cell, single-diode model could be widely used, and accurate in many cases [3].

\subsection{Ideal solar cell (1M3P)}

The characteristics of solar cells have an exponential behaviour similar to that of a diode [4]. The ideal equivalent circuit $f$ solar cell circuit is consists of (current source parallel with a single diode). This model is called (1M3P) and contain three parameters (m, $\mathrm{I}_{\mathrm{ph}}$ and $\mathrm{I}_{\mathrm{s}}$ ). The ideal equivalent circuit of solar cell is shown below.

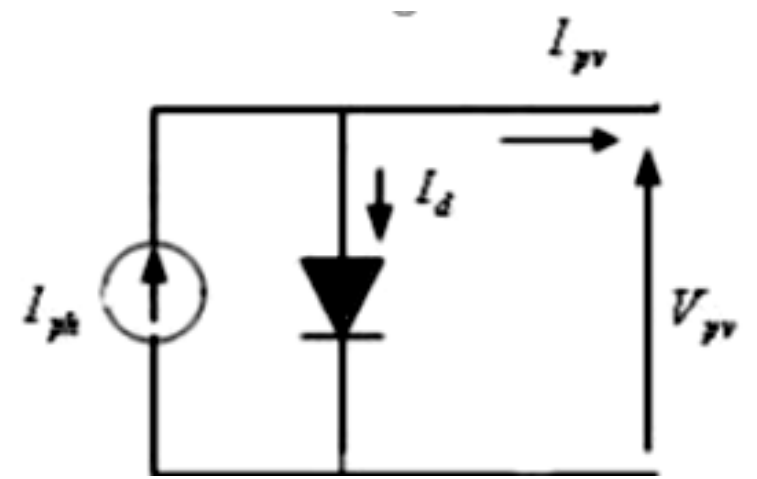

Fig. 1: Equivalent Model of Single Diode Ideal Solar Cel.

By applying Kirchhoff law:

$$
\mathrm{I}_{\mathrm{PV}}=\mathrm{I}_{\mathrm{Ph}}-\mathrm{I}_{\mathrm{d}}
$$

While, $I_{d}=I_{s}\left(\frac{q_{p v}}{e^{m K T}}-1\right)$ so the output current is presented by the following non-linear I-V equation:

$$
I_{P V}=I_{P h}-I_{s}\left(\frac{q^{2} v_{p v}}{e^{m K T}}-1\right)
$$

For the same $\mathrm{PN}$-junction temperature irradiation conditions $\mathrm{I}_{\mathrm{Sc}}$ and $\mathrm{V}_{\mathrm{oc}}$ are depicted as [5].

They are given by:

$$
\mathrm{I}_{\mathrm{sc}}=\mathrm{I}_{\mathrm{pv}}=\mathrm{I}_{\mathrm{ph}}
$$

For $\mathrm{VPV}=0$

$$
\mathrm{V}_{\mathrm{pv}}=\mathrm{V}_{\mathrm{oc}}=\frac{\mathrm{mkT}}{\mathrm{q}} \ln \left(1+\frac{\mathrm{I}_{\mathrm{sc}}}{\mathrm{I}_{\mathrm{s}}}\right)
$$

For IPV $=0$, the output power is: 


$$
P=V_{P V}\left[I_{s c}-I_{s}\left(e^{\frac{q V_{p v}}{m K^{T}}}-1\right)\right]
$$

\subsection{Solar cell with series resistance}

This model is called (1M4P) and has four parameters ( $\mathrm{m}, \mathrm{I}_{\mathrm{ph}}, \mathrm{I}_{\mathrm{s}}$ and $\mathrm{R}_{\mathrm{s}}$ ) and the equivalent circuit is shown below [6].

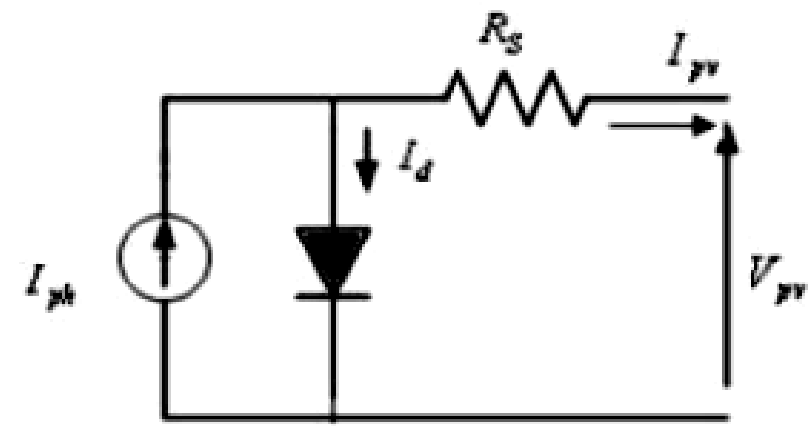

Fig. 2: Equilevvant Model of Single Diode Solar Cell with Series and Shunt Resistances (1MSP).

Where,

$$
I_{d}=I_{s}\left(e^{\frac{q\left(v_{p v}+R_{s} I p v\right)}{m k T}}-1\right)
$$

And

$$
I_{p v}=I_{p h}-I_{s}\left(e^{\frac{q\left(v_{p v}+R_{s} I_{p v}\right)}{m k T}}-1\right)
$$

The series resistance model involves recurrent equation to determine voltage at positive current.

\subsection{Solar cell with series and shunt resistance (1M5P)}

This model is called 1M5P and has five parameters ( $m, I_{p h}, I_{s}, R_{s h}$ and $R_{s}$ ). Equivalent circuit of PV cell is shown below [7].

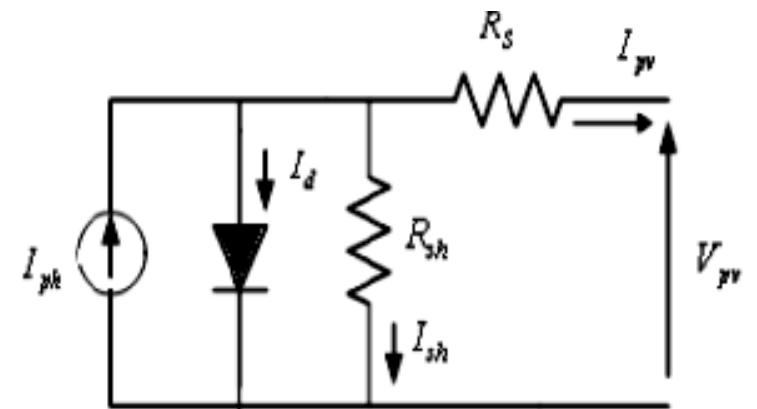

Fig. 3: Equilevvant Model of Single Diode Solar Cell with Series and Shunt Resistances (1MSP).

By applying Kirchhoff, law:

$$
I_{p h}=I_{p h}-I_{d}-I_{s h}
$$

Where,

$$
\begin{aligned}
& I_{d}=I_{S}\left(e^{\frac{q\left(V_{p v}-R_{s} I p v\right)}{m k T}}-1\right) \\
& I_{s h}=\frac{V_{p v}+R_{s} I_{p v}}{R_{s h}}
\end{aligned}
$$

And
$I_{p v}=I_{p h}-I_{S}\left(e^{\frac{q\left(v_{p v}-R_{S} I p v\right)}{m k T}}-1\right)-\frac{V_{p v}+R_{S} I_{p v}}{R_{S h}}$

\section{Model of solar PV array}

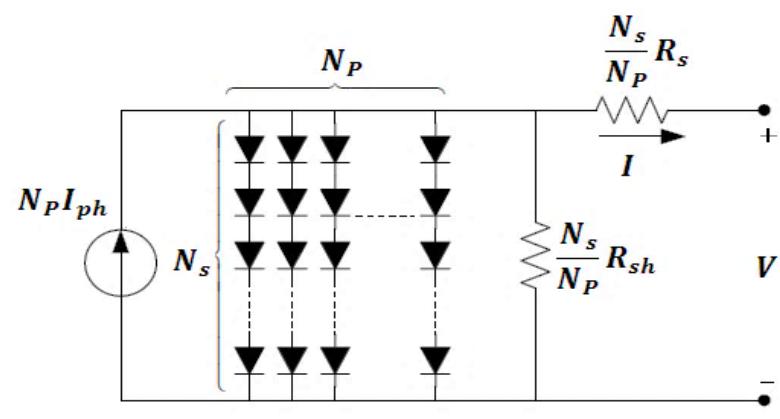

Fig. 4: Equivalent Circuit of Solar PV Array.

Order to produce high power, the cells must be connected in seriesparallel module configuration. This PV array is shown in figure 4[8 9]

The terminal equation for the current and voltage of the array becomes as follows:

$I=N_{P} I_{p h}-N_{P} I_{S}\left[e^{\left(q\left(V / N_{S}+I R_{S} / N_{P}\right) / A K T\right)}-1\right]-$ $\left(\frac{N_{P} V}{N_{s}}+I R_{S}\right) / R_{s h}$

The $R_{s h}$ and $R_{s}$ are significantly affect on PV output power. The simplified PV model with suitable complexity is shown in figure 5, and can be expressed as [8]

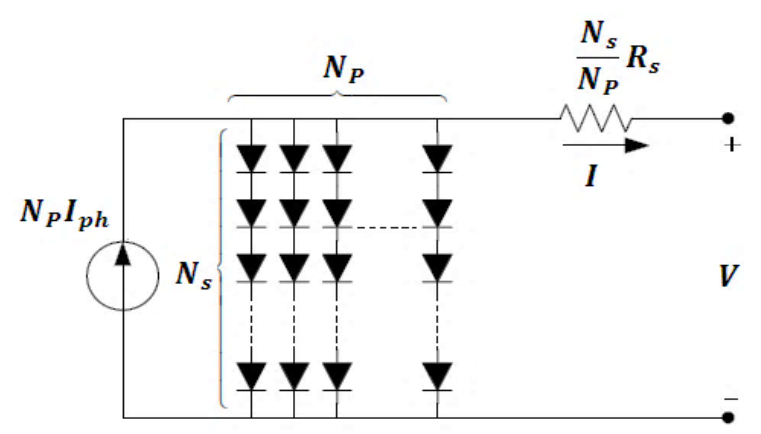

Fig. 5: Simplified Model of Solar PV Array.

$I=N_{P} I_{p h}-N_{P} I_{S}\left[e^{\left(q\left(V / N_{S}+I R_{S} / N_{P}\right) / A K T\right)}-1\right]$

The simplified PV model is depicted in figure 6 [8-9]. Equation (14) describes this equivalent circuit.

$I=N_{P} I_{p h}-N_{P} I_{S}\left[e^{\left(q V / N_{S} A K T\right)}-1\right]$

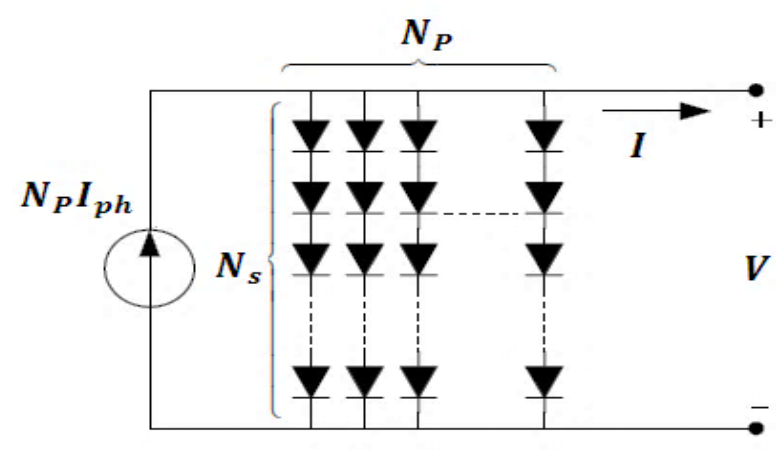

Fig. 6: Appropriate Model of Solar PV Array.

$I_{r S}=I_{s c} /\left[e^{\left(q V_{O C} / N_{S} A K T\right)}-1\right]$ 


\section{Mat lab sim ulink model}

The (LCS_M200_JA/SI) PV module is chosen in Matlab simulation and has the electrical specification as shown in table 1.

Table 1: Electrical Parameters of (LCS_M200_JA/SI) PV Cell

\begin{tabular}{ll}
\hline Dimensions & $1580 \times 808 \times 40 \mathrm{mw}$ \\
\hline Weight & $15.5 \mathrm{~kg}$ \\
Cell number & $72 \mathrm{monocrystalline}$ \\
$\mathrm{P}_{\mathrm{m}}$ & $200 \mathrm{WP}$ \\
$\mathrm{V}_{\mathrm{mp}}$ & $37.26 \mathrm{~V}$ \\
$\mathrm{I}_{\mathrm{mp}}$ & $5.37 \mathrm{~A}$ \\
Short circuit current $\left(I_{s h}\right)$ & $5.66 \mathrm{~A}$ \\
Open circuit voltage $\left(V_{o c}\right)$ & $45.62 \mathrm{~V}$ \\
\hline
\end{tabular}

The electrical circuit of PV-Cell was simulated by Matlab-program as shown in figure 7 .

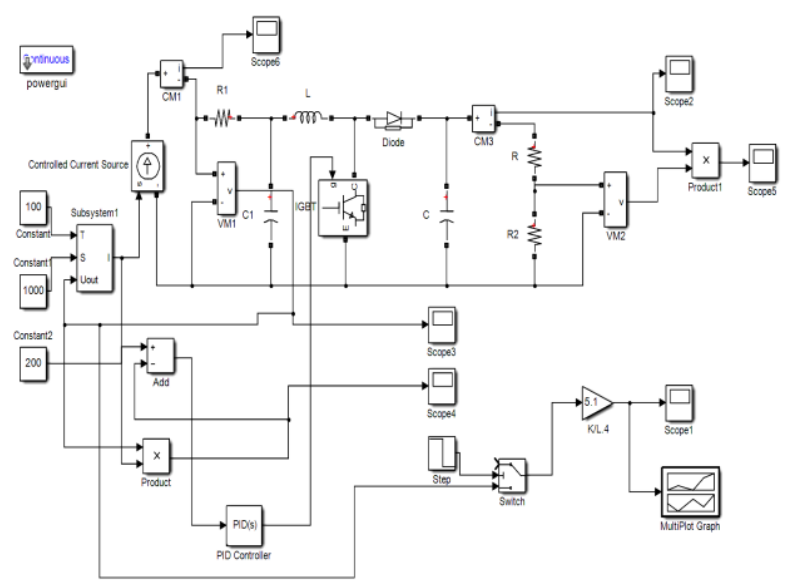

Fig. 7: Circuit Diagram of PV Cell.

\section{Influence of environmental and physical pa- rameter}

The influence of environmental and physical parameter is discussed in this paper.

\subsection{Influence of temperature}
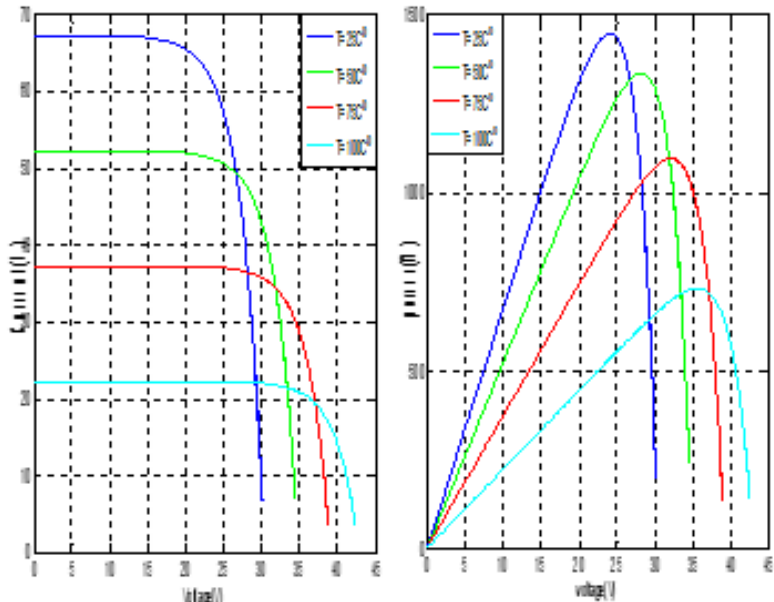

Fig. 8: Influence of Temperature.

Figure 8 , shows the I-V and P-V characteristics respectively under constant irradiation at $(1000 \mathrm{~W} / \mathrm{m} 2)$ and varying temperature. The current generated incident light increases slightly while the voltage decreases. When temperature decreases the power is increased.
Figure [9], shows the I-V and P-V characteristics respectively under constant temperature at $\left(25^{\circ} \mathrm{C}\right)$ and varying irradiation. It is clear that the higher irradiation gives greater current as a result maximum power point is obtained.
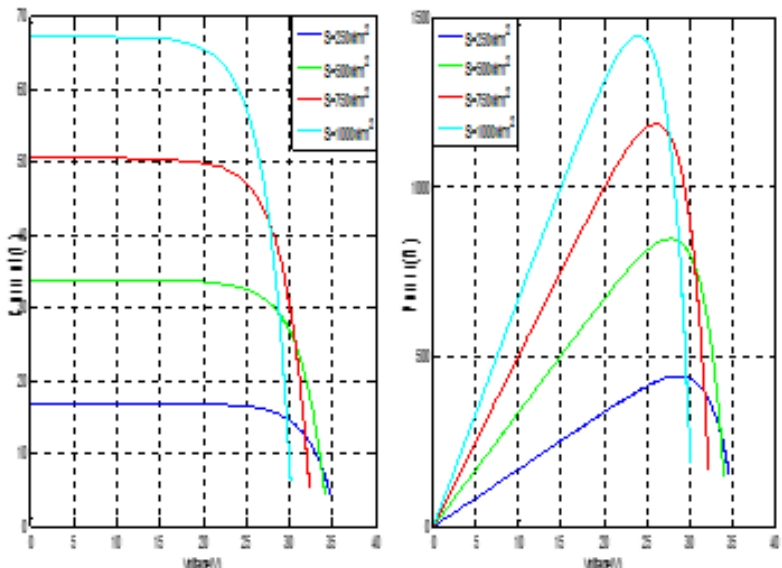

Fig. 9: Influence of Irradiation.

C. Influence of Series Resistance:

Figure 10 , shows the I-V and P-V characteristics respectively under influence of series resistance. As the series resistance value is increased the slope of I-V and P-V curves is decreased.
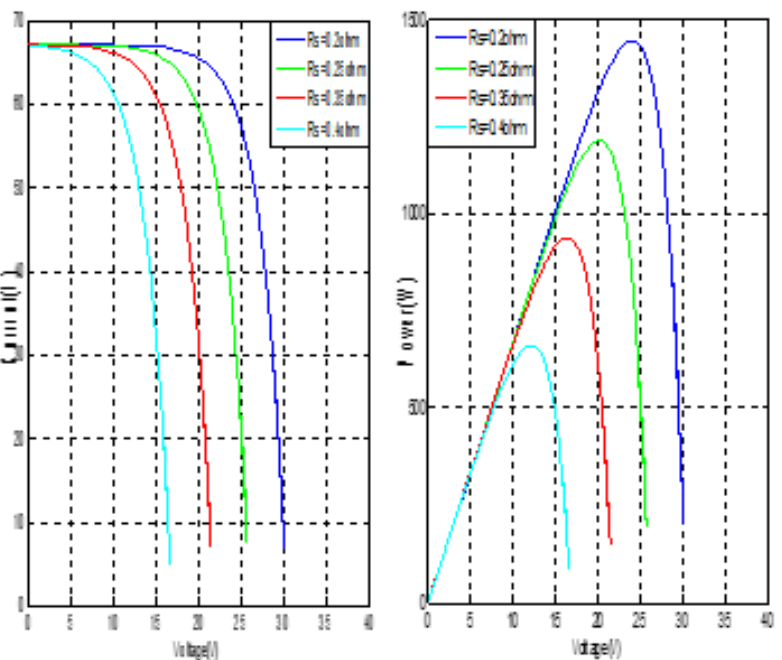

Fig.10: Influence of Series Resistance.

D. Influence of Shunt Resistance:

Figure 11, shows the I-V and P-V characteristics respectively under influence of shunt resistance. As the shunt resistance is increased the slope of (I-V) and (P-V) curves is increased.

\subsection{Influence of irradiation}



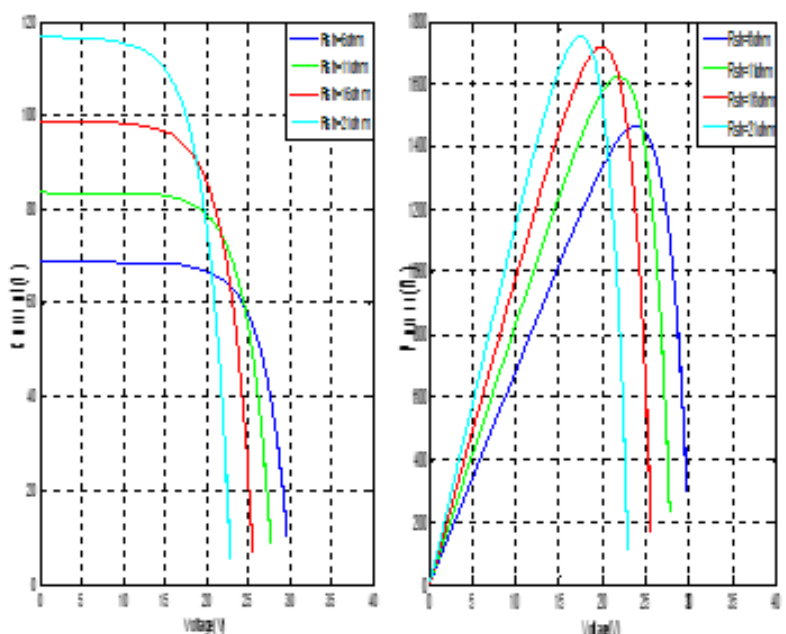

Fig. 11: Influence of Shunt Resistance.

\section{Practical model of solar power plant}

The practical structure of the PV panel and the solar power plant (In the Technical College of Mosul) are shown in figure12.

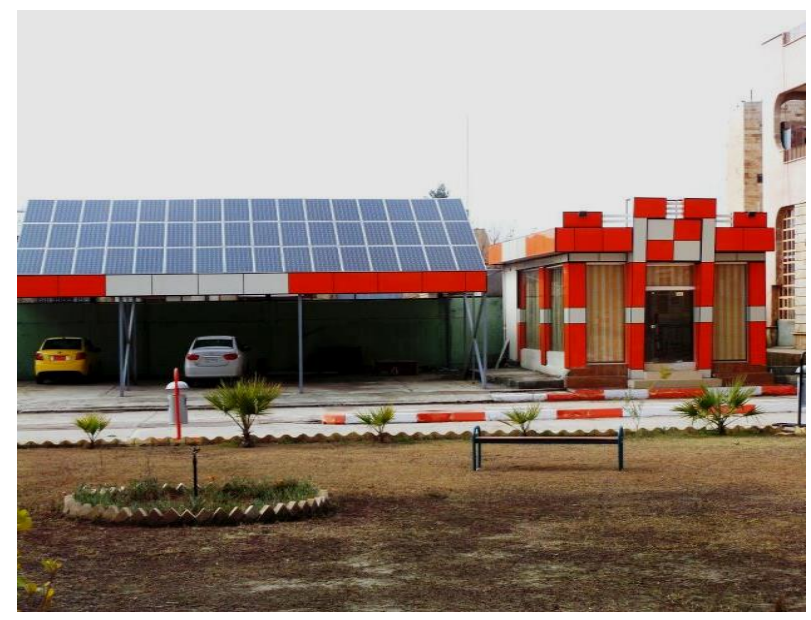

Fig. 12: Technical Collage of Mosul / Solar Power Plant.

The electrical schematic board of solar plant is shown in figure 13.

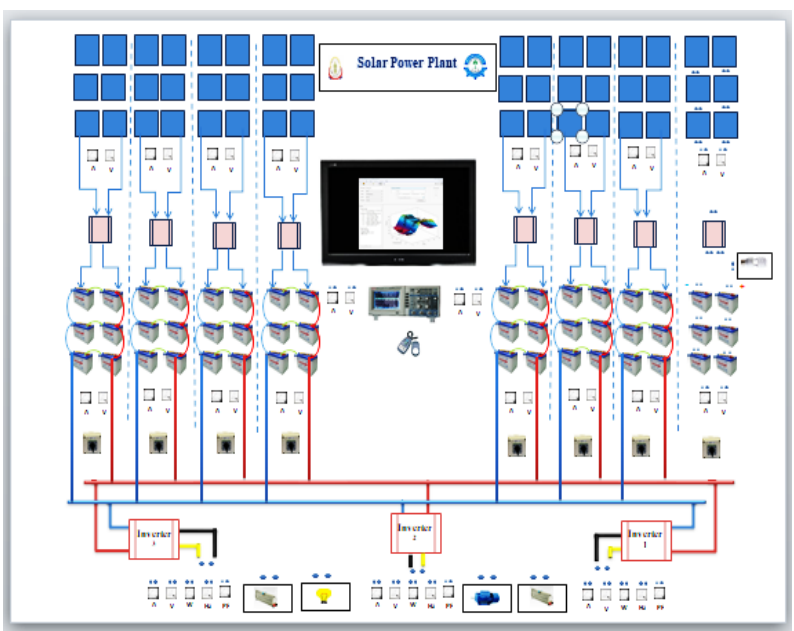

Fig. 13: Solar Power Plant Board.

The practical solar plant board is shown in figure 14 .

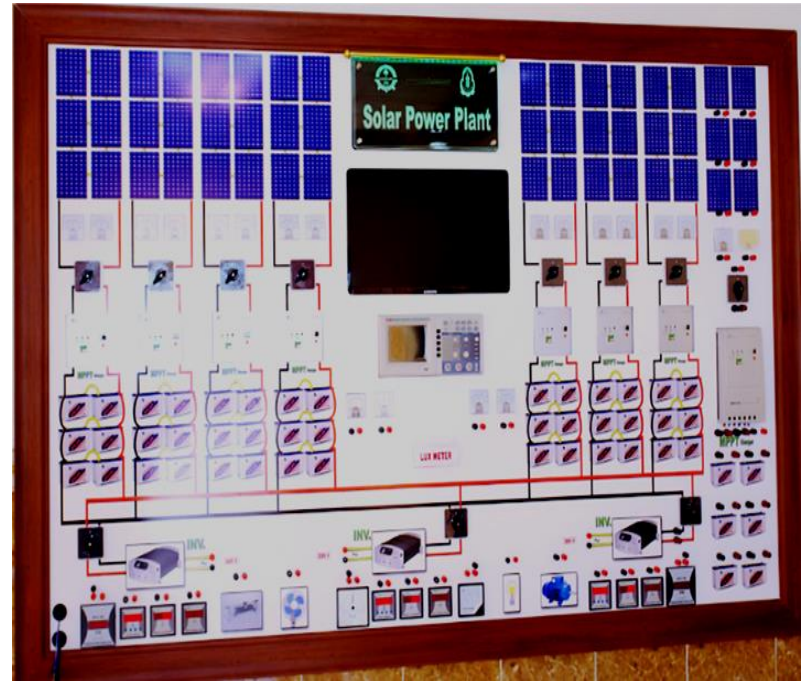

Fig. 14: Practical board of solar power plant.

\section{Practical results}

The effecting of temperature and irradiation on solar cell plant (Technical Collage of Mosul) is measured and implementation practically. Table [2] and table [3], represent the relationship between I-V and P-V of solar cell at temperature $25^{\circ} \mathrm{C}$, and constant irradiation $1000 \mathrm{~W} / \mathrm{m}^{2}$.

\begin{tabular}{ll} 
& Table.2: I-V Characteristics of Solar \\
\hline I (Amper) & V(Volt) \\
\hline 66.25 & 0 \\
66 & 5 \\
65.88 & 10 \\
65.85 & 15 \\
65 & 20 \\
64 & 22 \\
63.7 & 22.5 \\
60 & 24 \\
57 & 25 \\
54 & 26 \\
50 & 27 \\
40 & 28 \\
30 & 29 \\
\hline
\end{tabular}

Table.3 P-V Characteristics of Solar Cell at 25oc Cell At 25Co

\begin{tabular}{ll}
\hline $\mathrm{P}\left(\mathrm{W} / \mathrm{m}^{2}\right)$ & $\mathrm{V}($ Volt $)$ \\
\hline 0 & 0 \\
210 & 2.5 \\
380 & 5 \\
500 & 7 \\
680 & 10 \\
1000 & 15 \\
1340 & 20 \\
1420 & 22 \\
1450 & 23 \\
1420 & 26.5 \\
1250 & 27.5 \\
1000 & 28 \\
590 & 29 \\
\hline
\end{tabular}

The practical solar plant board is shown in figure 14. 

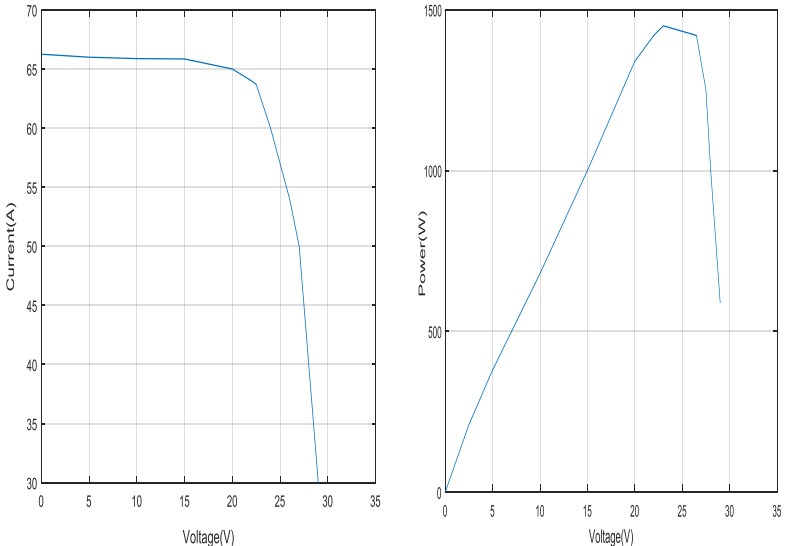

Fig. 15 Practical Influence of Temperature. of (Technical Collage of Mosul)

Table 4 and 5 represents the relationship between I-V and P-V of solar cell at irradiation $1000 \mathrm{~W} / \mathrm{m}^{2}$ and constant temperature $25^{\circ} \mathrm{C}$.

Table.4: I-V Characteristics of Solar Table.5. P-V Characteristics of Solar Cell at $1000 \mathrm{~W} / \mathrm{M}^{2} \mathrm{Cell}$ at $1000 \mathrm{~W} / \mathrm{M}^{2}$

\begin{tabular}{ll}
\hline $\mathrm{P}\left(\mathrm{W} / \mathrm{m}^{2}\right)$ & $\mathrm{V}($ Volt $)$ \\
\hline 0 & 0 \\
250 & 3.8 \\
500 & 7.5 \\
750 & 11.5 \\
1000 & 15 \\
1250 & 19 \\
1450 & 23.5 \\
1400 & 26 \\
1200 & 27.5 \\
1000 & 28 \\
750 & 29 \\
500 & 29.5 \\
250 & 30 \\
\hline
\end{tabular}

Table.5: P-V Characteristics of Solar

\begin{tabular}{ll}
\hline I (Amper) & V(Volt) \\
\hline 66.5 & 0 \\
66.25 & 5 \\
66 & 10 \\
65.8 & 20 \\
64 & 21.5 \\
62 & 23.5 \\
56 & 25 \\
50 & 27 \\
40 & 28 \\
30 & 28.5 \\
20 & 29 \\
5 & 30 \\
\hline
\end{tabular}
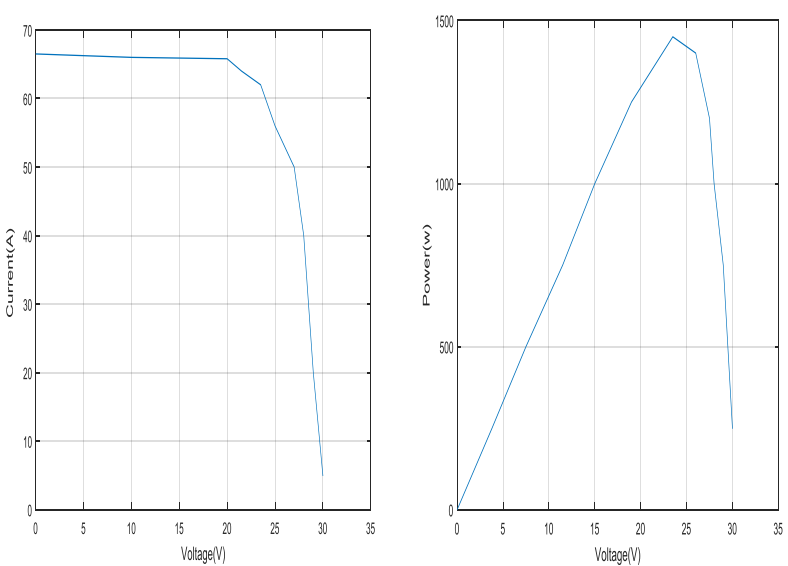

Fig.16: Practical influence of irradiation.
Fig.16: Represents the Influence of Irradiation at $\left(\mathrm{S}=1000 \mathrm{~W} / \mathrm{M}^{2}\right)$ and Constant Temperature $\left(\mathrm{T}=25 \mathrm{C}^{\circ}\right)$. This Influence Is Measured Practical On Solar Power Plant of Technical College of Mosul

\section{Conclusion}

This model so developed is used to shown the effect in I-V and P$\mathrm{V}$ characteristics of temperature, irradiation, shunt resistance and series resistance. The main objective of this paper is to show that single diode modeling is the most suitable model which can be used for simulation electrical behavior of PV module system for planning purpose in the field of power system.

We have presented the fundamental electric characteristics of photovoltaic cell of single diode where all the equivalent circuits were described, and the equivalent models were discussed. A comparison between these models demonstrated that the solar cell with series resistance model (1M4P) offers a more realistic behavior for the photovoltaic systems while it combines between the simplicity and the precision. The single diode model was analyzed in function of physical phenomena such as the shunt resistance and series resistance, and the environmental parameters as the irradiation and the temperature.

The simulation results shown the model behaves appropriately with the characteristics of the system to be modeled. Further, the modeled MPPT could make the solar power plant to find the maximum power extracted from the solar (PV) panel.

\section{References}

[1] J. Bikaneriaet al., "Modeling and simulation of PV cell using onediode model," IJSRP, vol. 3, issue 10, 2013.

[2] N. Belhaouas, M. S. A. Cheikh, A. Malek, and C. Larbes, "MatlabSimulink of photovoltaic system based on a two-diode model simulator with shaded solar cells," Revue des Energies Renouvelables, vol. 16 , no. 1 , pp. $65-73,2013$.

[3] E.M.G. Rodrigues, R. Melício, V.M.F. Mendes, and J.P.S. Catalão, Simulation of a solar cell considering single-diode equivalent circuit model, international conference on renewable energies and power quality, icrepq'11, las palmas, spain, (2011).

[4] B. Bentouati, "Etude comparative deux cellules photovoltaqïues," Master in automatic control, University of Djelfa, 2012.

[5] B. Alsayid, "Modeling and simulation of photovoltaic cell $/ \mathrm{mod}$ ule/array with two-diode model," IJCTEE, vol. 1, no. 3, 2012.

[6] D. Bonkoungou, Z. Koalaga, and D. Njomo, "Modelling and simulation of photovoltaic module considering single-diode equivalent circuit model in Matlab," International Journal of EmergingTechnology, vol. 3, issue 3, 2013.

[7] T. Salmi et al., "Matlab-Simulink based modeling of solar photovoltaic cell," international journal of renewable energy research, vol. 2, no. 2, 2012.

[8] K. Hellali, "Modelisationd'une cellule photovoltaique: etude comparative," Master in Electrotechnique, UniversiteMouloudMammri de Tizi-Ouzou, 2012.

[9] A. Ould Mohamed yahya, A. Ould Mohamed and I. Youm, Etude.centre de recherchea ppliquée aux energies renouvelables'Craer',Université de Nouakchott, 19 Juillet 2008 - accepté le 30 Septembre 2008) 